TITLE:

\title{
Age-related remodelling of oesophageal epithelia by mutated cancer drivers(Abstract_要旨)
}

$\operatorname{AUTHOR}(\mathrm{S})$ :

Yokoyama, Akira

\section{CITATION:}

Yokoyama, Akira. Age-related remodelling of oesophageal epithelia by mutated cancer drivers. 京都大学, 2019, 博士(医学)

ISSUE DATE:

2019-09-24

URL:

https://doi.org/10.14989/doctor.k22036

\section{RIGHT:}

Final publication is available at

https://www.nature.com/articles/s41586-018-0811-x 


\begin{tabular}{|c|c|c|c|}
\hline 京都大学 & 博士（医学） & 氏 名 & 横 山 顕 礼 \\
\hline 論文題目 & $\begin{array}{l}\text { Age-related remode } \\
\text { 加齢に伴う食道上) }\end{array}$ & $\begin{array}{l}\text { esophageal } \\
\text { ドライバ }\end{array}$ & $\begin{array}{l}\text { mutated cancer drivers } \\
\text { るリモデリング }\end{array}$ \\
\hline 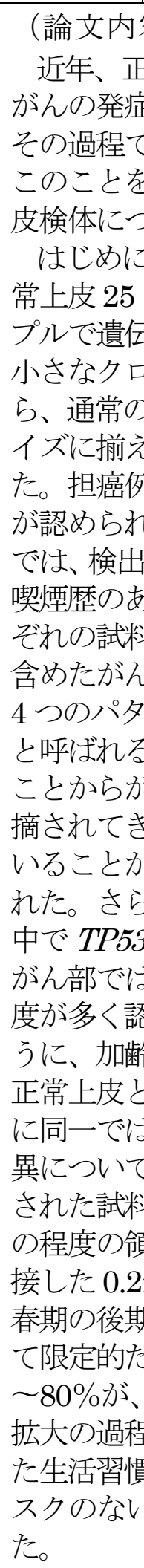 & 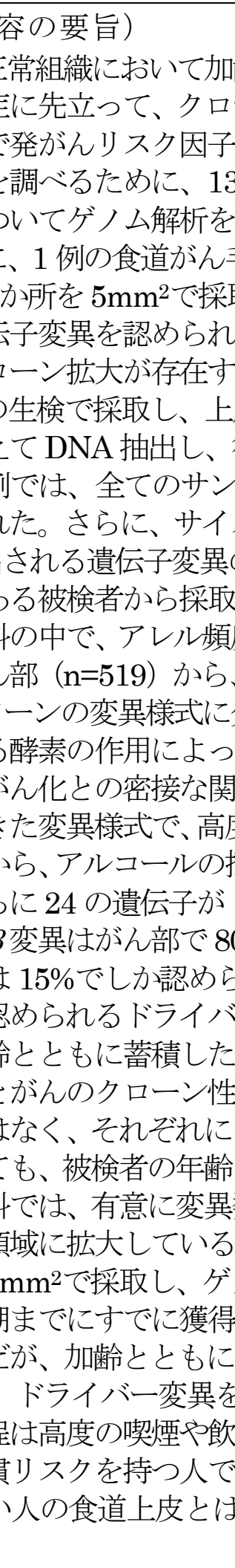 & 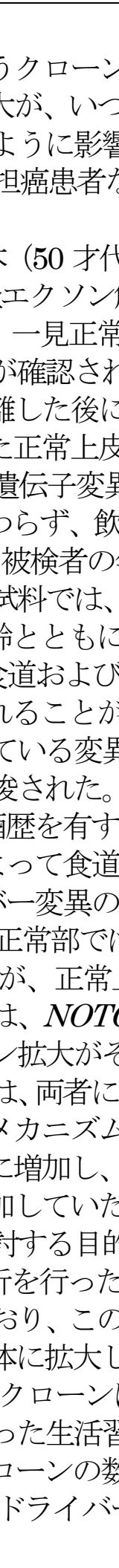 & 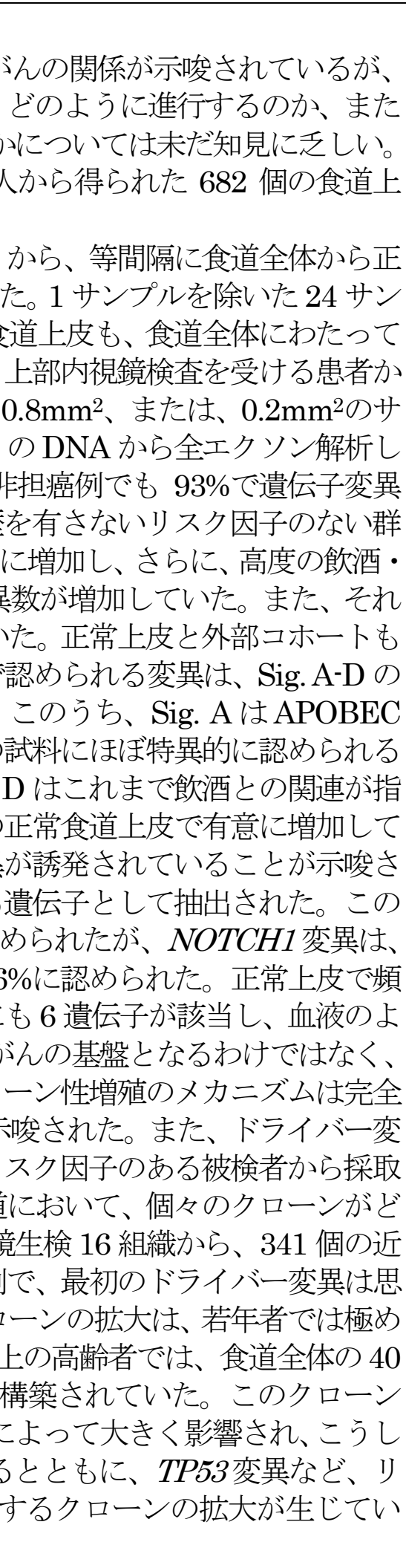 \\
\hline
\end{tabular}

（論文審査の結果の要旨）

正常組織において加龄に伴うクローン拡大が、がん発生に関係していることは既に知ら れている。しかし、がん化する前に、クローン拡大が、いつ獲得され、どのように進行 するのか、またその過程で発がんリスク因子がどのように影響を及ぼすのかは解明され ていない。今回 682 サンプルの微小な食道上皮試料を用いてゲノム解析を行い、正常食 道上皮では、NOTCH1 変異を主体と寸るドライバー変異を獲得したクローンが加齢とと もに拡大し、そのクローン拡大は過度の飲酒や喫煙により促進することを明らかにした。 ドライバー変異を獲得したクローンは多中心性に年少期のうちに出現しており、これに 引き続いて複数のドライバー変異を獲得してクローン拡大が生じ、加齢とともにその数 やサイズが増加し、高齢者では正常食道の大半がドライバー変異を有するクローンに置 き換わっていることを明らかにした。ドライバー変異を獲得したクローンによる食道上 皮の再構築は加齢による不可避な変化であり、過度の飲酒・喫煙により促進されると考 えられる。

以上の研究は、がんの初期発生過程の解明に貢献し、がんが高齢者で多発し過度の喫煙 や飲酒といった発がんリスクにより食道がんの発生が増加するメカニズムの解明に寄与 するところが多い。したがって、本論文溥士（医学 ）の学位論文として価值あるもの と認める。

なお、本学位授与申請者は、令和 1 年 6 月 28 日実施の論文内容とそれに関連し た試問を受け、合格と認められたものである。 